\title{
An Arctic Ozone Hole in 2020 If Not For the Montreal Protocol
}

\author{
Catherine Wilka ${ }^{1}$, Susan Solomon ${ }^{1}$, Doug Kinnison ${ }^{2}$, David Tarasick ${ }^{3}$
}

${ }^{1}$ Department of Earth, Atmospheric and Planetary Sciences, Massachusetts Institute of Technology, Cambridge, MA, USA

${ }^{2}$ Atmospheric Chemistry Division, National Center for Atmospheric Research, Boulder, CO, USA

$5 \quad{ }^{3}$ Environment and Climate Change Canada, Toronto, ON, Canada

Correspondence to: Catherine Wilka (cwilka@mit.edu)

\begin{abstract}
Without the Montreal Protocol the already extreme Arctic ozone losses in boreal spring of 2020 would be expected to have produced an Antarctic-like ozone hole, with an area of total ozone below 220 DU of about $20 \mathrm{million}^{2} \mathrm{~km}^{2}$. Record observed local lows of $0.1 \mathrm{ppmv}$ at some altitudes in the lower stratosphere would have reached 0.01, again similar

10 to the Antarctic. This provides an opportunity to test parameterizations of polar stratospheric cloud impacts on denitrification, and thereby to improve stratospheric models. Spring ozone depletion would have begun earlier and lasted longer without the Montreal Protocol, and by 2020 the year-round ozone depletion would have begun to dramatically diverge from the observed case. This study reinforces that the historically extreme 2020 Arctic ozone depletion is not cause for concern over the Montreal Protocol's effectiveness, but rather demonstrates that the Montreal Protocol indeed merits 15 celebration for avoiding an Arctic ozone hole.
\end{abstract}




\section{Introduction}

In the 1970s, Molina and Rowland issued a prescient warning to humanity that the chlorofluorocarbons (CFCs)

20 contained in popular refrigerants, building foams, and aerosol cans posed a danger to the stratospheric ozone layer (Molina and Rowland, 1974). This threat, initially thought to be a worry for the next century, suddenly transformed into a pressing concern with the discovery of unexpected, deep springtime depletion in the Antarctic polar vortex (Farman, 1985), which became known to the world as the "ozone hole." Subsequent work (Solomon et al., 1986) revealed that heterogeneous chemical reactions involving chlorine on the cold surfaces of Polar Stratospheric Clouds (PSCs) were the primary culprit behind this deep depletion, and several studies highlighted a significant role for sedimentation of large particles carrying $\mathrm{HNO}_{3}$, or denitrification (Toon et al., 1986; Crutzen and Arnold, 1986). Definitions for what constitutes an ozone hole have been debated in the scientific literature (see Langematz et al., 2018 and references therein) but for purposes of comparison to the discovery of the Antarctic ozone hole and its impact on policy of the era, here we use the historical definition of total ozone area below 220 Dobson Units (Stolarksi et al., 1990). Another important metric is extreme locally depleted ozone mixing ratios in the lower stratosphere (Hofmann et al., 1997), providing an important fingerprint for chemical ozone loss driven by chlorine chemistry on PSCs. In response to the increasing ozone depletion, the global community came together to pass the 1987 Montreal Protocol on Substances that Deplete the Ozone Layer, more commonly referred to as the Montreal Protocol. The Montreal Protocol, and its subsequent amendments during the 1990s, mandated the decrease and eventual cessation of worldwide production of ozone depleting substances (ODSs) such as CFCs (Birmpili, 2018).

Within the past few years, ever-stronger evidence for global ozone stabilization and a nascent Antarctic ozone recovery has emerged (Solomon et al., 2016; Sofieva et al., 2017; Chipperfield et al., 2017; Strahan and Douglass 2018). Despite uncertainties surrounding continuing CFC emissions from both scattered rogue production (Montzka et al., 2018) and existing stores in building foams and other banks (Lickley et al., 2020), the world appears to be on track for near-complete ozone recovery by the second half of the $21^{\text {st }}$ century, and the Protocol has been ratified by every state represented at the United Nations. No other global environmental treaty can claim such a resounding success.

Success of the Montreal Protocol, however, should be measured not just by emission adherence but by the harm to the earth system and human society that its passage avoided. The first study on such a "World Avoided" (WA) by (Prather et al.,

45 1996) found strong evidence that the Antarctic ozone hole would have continued to worsen on average. Subsequent studies broadened to examine variability from year to year and at various longitudes. A decade later, (Morgenstern et al., 2008) studied WA in a more detailed three-dimensional model and found significant ozone decline in the upper stratosphere and polar vortices, a transition in the Arctic from dynamical to chemical control, and major regional climate impacts caused by 
dynamical changes. The first fully interactive time-evolving global study of the world avoided by the Montreal Protocol, by (Newman et al., 2009), found increasingly extreme impacts throughout the $21^{\text {st }}$ century. Their simulations for the WA predicted Arctic column ozone levels of 220 DU or less by 2030, with some minimum values within the vortex that low by 2020 in extreme cold years. The associated column depletion was predicted to yield a 550\% increase in DNA damage when compared to 1980 by 2065 for NH midlatitudes. Chipperfield et al. (2015) examined the WA for the recent extreme cold year of 2011. They found that Arctic ozone levels would indeed have dropped below 220 DU in that year in the WA, but in a limited region that did not span the entire pole as in the Antarctic, as we discuss in Section 3.

The Arctic spring of 2020 displayed very cold temperatures and a stable polar vortex that led to record levels of Arctic PSCs, and deep observed Arctic ozone depletion in the real world at some altitudes in the lower stratosphere (Wohltmann et al., 2020; Manney et al., 2020). While the classical definition of an ozone hole (a significant areal extent below 220 DU) did not occur in 2020, many news reports characterized it as such, sparking public uncertainty over whether humanity has really solved the problem of ozone depletion. Here we seek to examine the chemistry and ozone depletion of both the real world and of that obtained in a world without the Montreal Protocol to evaluate what 2020 implies for the Montreal Protocol's achievements in the context of Arctic ozone loss.

\section{Methods and Data}

\subsection{Model}

We use the Specified Dynamics version of NCAR's Whole Atmosphere Community Climate Model (SDWACCM) to compare the ozone depletion and chemistry in a simulation of the real world (RW) to one in which ODSs continued to increase at 3.5\% per year from the year 1985 onwards. The Community Earth System Model, version 2 (CESM2) WACCM is a superset of the Community Atmosphere Model, version 6 (CAM6), which extends from the Earth's surface to the lower thermosphere (Gettelman et al., 2019). WACCM includes updated representations of boundary layer processes, shallow convection and liquid cloud macrophysics, and two-moment cloud microphysics with prognostic cloud mass and concentration (Danabasoglu et al., 2020). Aerosol representation for dust, sea-salt black carbon, organic carbon, and sulfate in three size categories is prognostic in this version (Mills et al., 2016). We use the specified dynamics (SD) version of WACCM, where the atmosphere below $50 \mathrm{~km}$ is nudged to the Modern-Era Retrospective Analysis for Research and Applications version 2 (MERRA-2; Gelaro et al., 2017) temperature and wind fields with a relaxation time of 50 hours. There are 88 vertical pressure grid levels from the ground to the thermosphere $(\sim 140 \mathrm{~km})$, with the altitude resolution increasing from $\sim 0.1 \mathrm{~km}$ near the surface to $\sim 1.0 \mathrm{~km}$ in the UTLS and $\sim 1-2 \mathrm{~km}$ in the stratosphere. The horizontal resolution is $1.95^{\circ} \times 2.5^{\circ}$ in latitude and longitude. The chemistry mechanism used in this study includes a detailed representation of the middle atmosphere, with a sophisticated suite of gas-phase and heterogeneous chemistry reactions including the $\mathrm{O}_{\mathrm{x}}, \mathrm{NO}_{\mathrm{x}}$, 
$\mathrm{HO}_{x}, \mathrm{ClO}_{x}$, and $\mathrm{BrO}_{\mathrm{x}}$ reaction families (Kinnison et al., 2007). There are $\sim 100$ chemical species and $\sim 300$ chemical reactions. Reaction rates are updated following JPL 2015 recommendations (Burkholder et al., 2015). The model's volcanic sulfur loading is from the Neely and Schmidt (2016) database, and has been updated through the Raiakoke eruption in 2019. Polar Stratospheric Clouds (PSCs) are present below $\sim 200 \mathrm{~K}$ as solid nitric acid trihydrate (NAT), water ice, and supercooled ternary solutions ( $\underline{\text { Solomon et al., 2015) }}$. As described further in Sec 3, to simulate ozone loss more accurately we tested multiple values of the NAT particle number density controlling denitrification ranging from the default of 0.01 particles per $\mathrm{cm}^{3}$ to $10^{-5}$ particles per $\mathrm{cm}^{3}$. For the WA simulation we used the smallest value.

The Real World runs use the Coupled Model Intercomparison Project phase 6 (CMIP6) hindcast scenario (Meinshausen et al., 2017) based on observations for the evolution of ODSs and other emissions through 2014. The period 2015 through April 2020 uses the CMIP6 Shared Socioeconomic Pathways (SSP) 585 projection (O'Neill et al., 2016). The WA run assumes a $3.5 \%$ per year increase beginning in 1985 in all organic chlorine and bromine species, except for $\mathrm{CH}_{3} \mathrm{Cl}_{,} \mathrm{CH}_{2} \mathrm{Br}_{2}, a_{1}$ $\mathrm{CHBr}_{3}$, which mainly have natural sources (Figure $\mathrm{S} 1$ ). $\mathrm{CH}_{3} \mathrm{Br}$ is assumed to be half from natural sources, half from anthropogenic, so that its increase is half that of the other ODSs.

\subsection{Satellites}

We compare SD-WACCM's total column ozone values to those observed by NASA's Ozone Monitoring Instrument (OMI) on the Earth Observing System (EOS) Aura satellite (Bhartia, 2012). OMI is a nadir-viewing wide-fieldimaging spectrometer that continues the global total column ozone record from NASA's Total Ozone Mapping Spectrometer (TOMS). We use the Level 3 gridded data product here for comparison with SD-WACCM's daily column ozone values.

100 Level 3 data is generated from high-quality only Level 2 data and is available on a daily basis. When calculating daily polar cap minimum total ozone values we filter data at solar zenith angles above $82^{\circ} \mathrm{N}$ to remove spurious points.

We compare SD-WACCM's $\mathrm{HNO}_{3}$ mixing ratios to those observed by NASA's Microwave Limb Sounder (MLS) on the EOS Aura satellite (Waters et al., 2006). MLS has been continuously observing the upper atmosphere since its launch in

105 2004, although data gaps exist, including during the second half of March through early April 2020. MLS data was processed according to the flags and thresholds described in the Version 4.2x Level 2 Data Quality and Description Document. The vertical resolution of the $\mathrm{HNO}_{3}$ data at the levels of interest is 3-4 km, with a reported measurement precision of $\pm 0.6 \mathrm{ppbv}$ and a systematic uncertainty of $\pm 1.0 \mathrm{ppbv}$. MLS data was binned into a $5^{\circ} \times 5^{\circ}$ latitude-longitude grid before plotting.

\subsection{Ozonesondes}

We use balloon-based ozonesondes to examine ozone mixing ratios at individual levels and in vertical profiles. Ozonesondes are launched at regular intervals from multiple stations across the globe and collated by the WOUDC. We use 
data from Resolute, Ny-Ålesund, Sodankyla, Eureka, Alert, Lerwick, and Thule to represent the historical record. All data in recent decades are from electrochemical concentration cell (ECC) ozonesondes, which have a precision of 3-5\% and an overall uncertainty in ozone concentration of about $\pm 10 \%$ up to $30 \mathrm{~km}$ (Smit et al., 2007; Tarasick et al., in press). The ozone sensor response time of $\sim 25 \mathrm{~s}$, for a typical balloon ascent rate of $4-5 \mathrm{~m} / \mathrm{s}$, gives ozonesondes a vertical resolution of about 100-150 meters. Pre-1980 data from Resolute are from older Brewer-Mast sondes, which have a precision of about 5-10\%

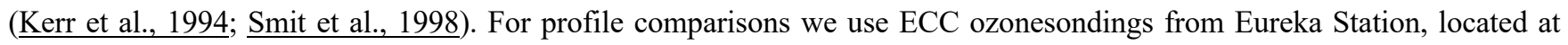
$80.04^{\circ} \mathrm{N},-86.18^{\circ} \mathrm{E}$, along with simultaneously measured temperatures.

\section{Results}

Figure 1 shows the total column ozone (TCO) that would have been expected in the World Avoided (top left) on the day of greatest ozone depletion in 2020 in the model, March $13^{\text {th }}$, compared to that expected and observed in the RW run (top right, bottom right) for the same day. The area meeting the standard definition of an ozone hole in the WA is nearly 20 million $\mathrm{km}^{2}$, a comparable areal extent to many observed past Antarctic ozone holes, and the region below 150 DU stretches across the North Pole and over significant parts of Canada, Greenland, and Russia. By comparison, while the depletion in the RW case is clearly visible, it never breaches the 220 DU threshold for any significant area. Observations from OMI (lower right) support this, although the higher resolution satellite finds small, isolated patches below $220 \mathrm{DU}$. The difference between the WA and RW runs (lower left) is $20 \mathrm{DU}$ or more throughout the Northern Hemisphere, and maximizes at over 130 DU in the Arctic. We can compare this to another recent cold year, 2011 (Figure S2), previously highlighted by others for its large Arctic ozone losses in WA simulation (Chipperfield et al. (2015); we note that our study follows a slightly different WA emissions path, with a different partitioning between anthropogenic and natural emissions for $\mathrm{CH}_{3} \mathrm{Br}$ in particular, compare our Figure S1 with their Figure 1a). In our simulations, the expected Arctic ozone hole in 2011 is much smaller in area than in 2020 (11.08 million $\mathrm{km}^{2}$ vs 19.71 million $\mathrm{km}^{2}$ ). In summary, without the Montreal Protocol, the 2020's combination of extreme meteorology and increased chlorine loading would have resulted in unprecedented Arctic ozone depletion and an Arctic ozone hole comparable in areal extent to those of the Antarctic, with the accompanying impacts on UV levels throughout the Arctic.

To confirm the historically anomalous nature of 2020 and to evaluate our model's performance in more detail, we examine a time series of measurements at the $50 \mathrm{mb}$ pressure level from archived Arctic ozonesondes, shown in the left panel of Figure

140 2. Because 2020 displayed very large local changes in Arctic ozone, the less-precise measurements from older Brewer-Mast sondes are also valuable for this purpose and are shown with open symbols. The long ozonesonde record allows us to compare to historical values predating the start of the satellite era in 1979, which is especially important for ozone trends as there may have been some depletion already by that time. Figure 2 shows ozone values for available days in March, stacked 
https://doi.org/10.5194/acp-2020-1297

Preprint. Discussion started: 8 January 2021

(c) Author(s) 2021. CC BY 4.0 License.

(c) (1)

by year, and demonstrates that 2020 displays ozone amounts lower than any other year in the record at this altitude (including 2011, which displays the next deepest depletion). This is especially apparent in the log-scale version in Figure S3.
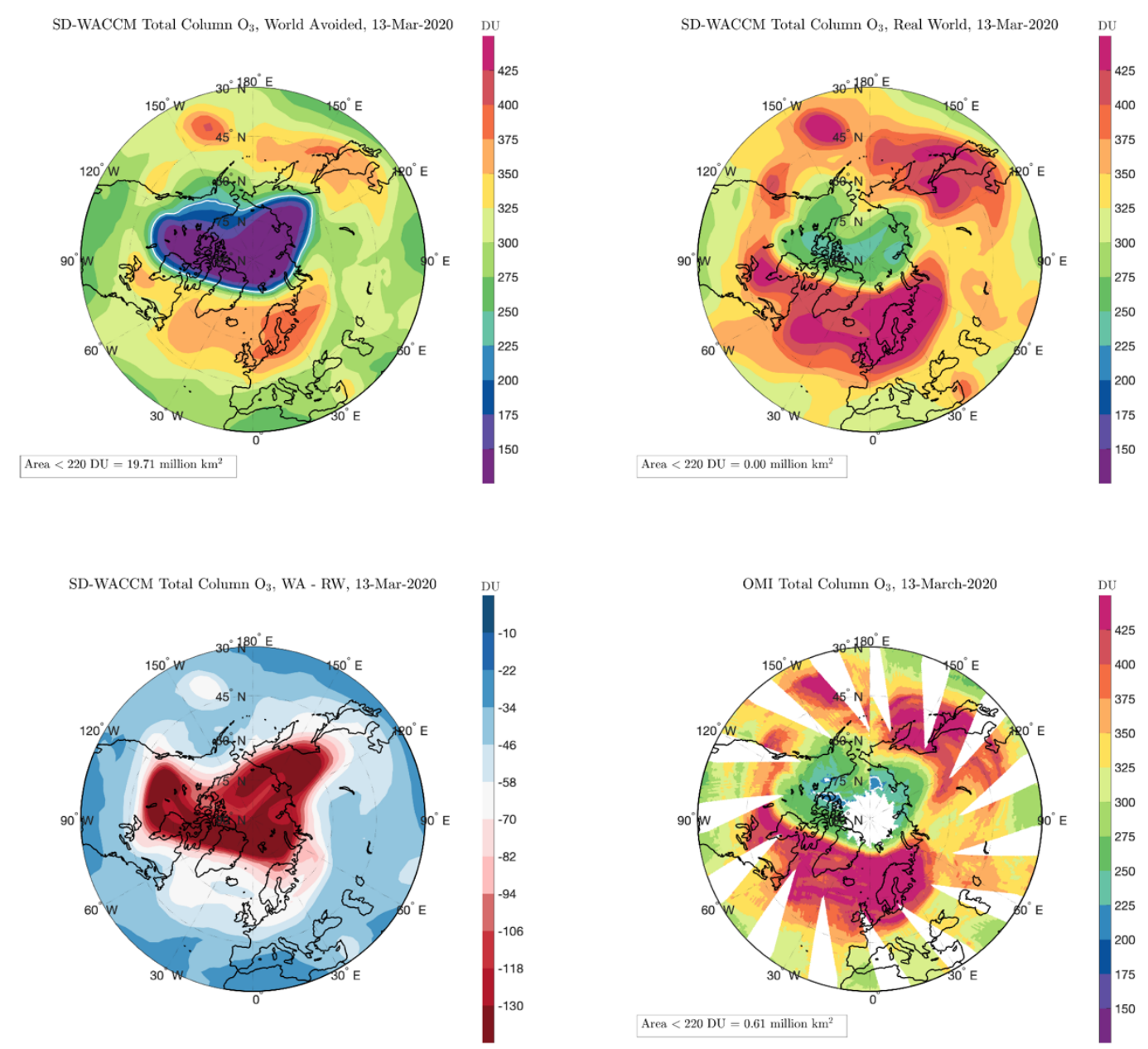

Figure 1. Total Column Ozone poleward of $30^{\circ} \mathrm{N}$ for March 13, 2020. The upper left figure shows the World Avoided SDWACCM run, the upper right figure shows the Real World run, and the lower left shows the difference between them. The lower right figure shows the Total Column Ozone Level 3 product from the OMI satellite. All levels are in Dobson Units. Note the different scale on the lower left colorbar. The 220 DU contour is outlined in white. 
(a)

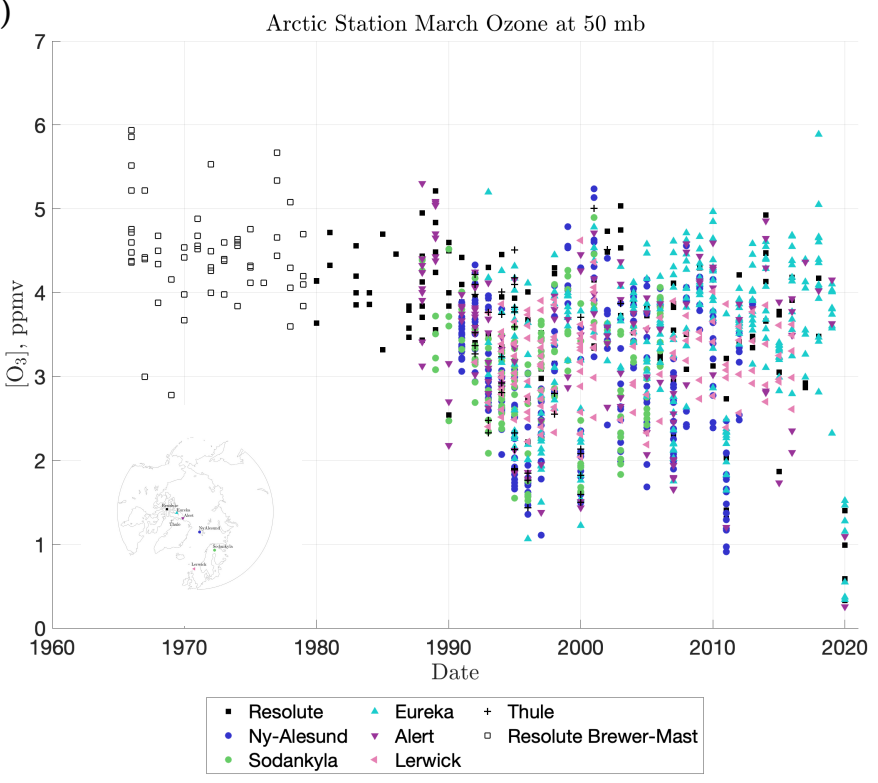

(b)

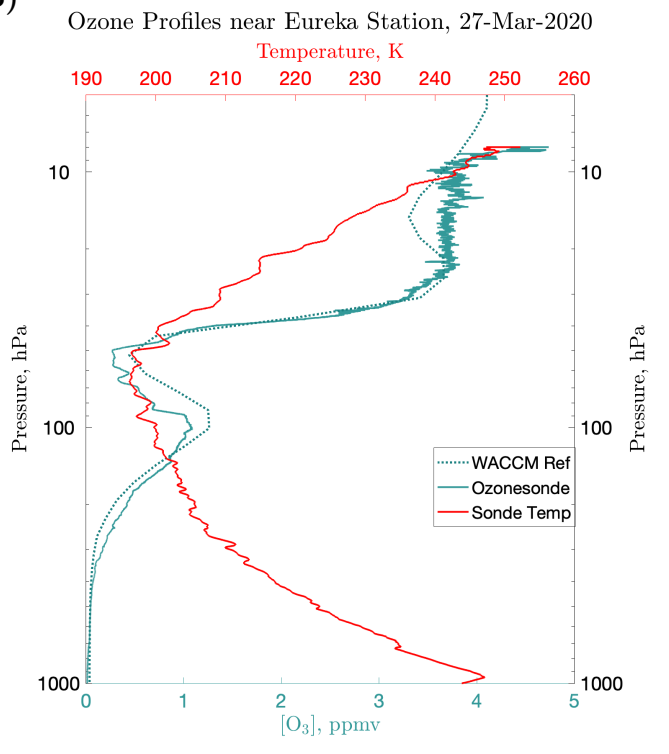

Figure 2. (a) Daily ozone values centered at $50 \mathrm{mb}( \pm 2.5 \mathrm{mb})$ from ozonesondes launched from various stations across the northern polar region in March. Measurements using less accurate methods are indicated with open symbols. The location of these stations is shown in the lower left corner of the panel. (b) Ozone and temperature profiles taken at Eureka station on March $27^{\text {th }}, 2020$, compared to the SD-WACCM Real World run's vertical profile at the nearest model gridpoint.

The right panel of Figure 2 compares the vertical profile of ozone at the nearest model grid point to Eureka station data for March $27^{\text {th }}, 2020$, showing some of the lowest values of stratospheric ozone ever recorded in the Arctic. The figure shows that the largest depletion here tracks the lowest local temperatures. Eureka is near the center of the lowest total ozone on this date and is representative of the region based upon the model, and on comparisons with other high-Arctic sites, which show similar profiles. Although temperature histories can also be important, this broadly supports the view that much of this year's ozone loss was related to cold temperatures increasing the efficiency of heterogeneous reactions on PSCs (Wohltmann et al., 2020; Manney et al., 2020). Figure 2 illustrates that the SD-WACCM model successfully captures the observed behavior at this site under these extreme conditions.

We next test how SD-WACCM's nitric acid trihydrate (NAT) number density count relates to calculated denitrification (Fahey et al., 2001) using comparisons to nitric acid observations from the Microwave Limb Sonder (MLS) satellite (Waters et al., 2006) and ozonesonde profiles. Polar stratospheric clouds not only activate chlorine through heterogeneous chemical 
https://doi.org/10.5194/acp-2020-1297

Preprint. Discussion started: 8 January 2021

(C) Author(s) 2021. CC BY 4.0 License.

(a)

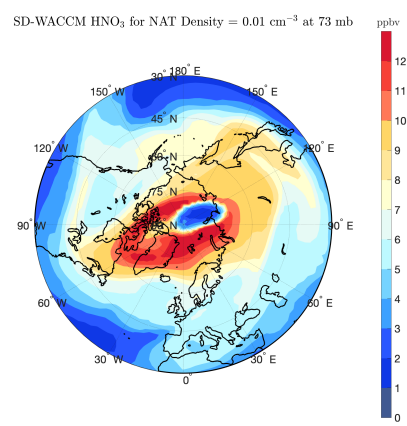

(c)

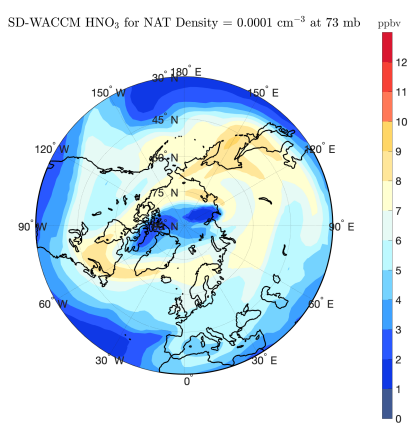

(b)

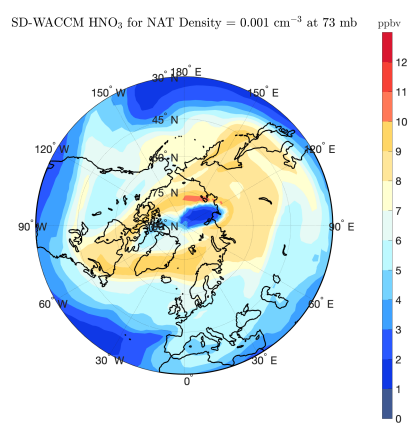

(d)

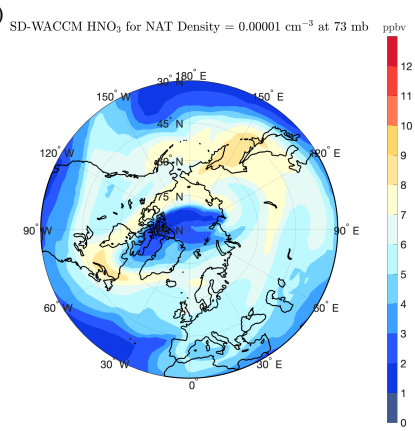

(e)

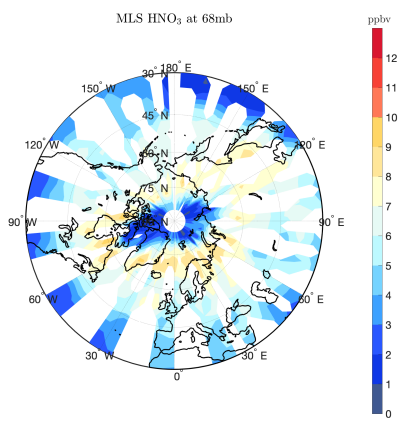

170 Figure 3. $\mathrm{HNO}_{3}$ in ppbv for February $20^{\text {th }}, 2020$, for different NAT parameterizations in SD-WACCM compared to MLS. All SD-WACCM figures show the $73 \mathrm{mb}$ level; MLS shows the $68 \mathrm{mb}$ level.

processing but also denitrify the atmosphere through removal of $\mathrm{HNO}_{3}$ from the gas phase and sedimentation. Removing $\mathrm{HNO}_{3}$ reduces the abundance of $\mathrm{NO}_{2}$, which in turn enhances active chlorine (i.e., $\mathrm{ClO}$ abundances) by reducing $\mathrm{ClONO}_{2}$ formation rates, affecting ozone destruction chemistry. Initial comparisons with MLS showed that the model's standard approach ( $\underline{\text { Wegner et al., 2013 }}$ ) was denitrifying too little. Figure 3 shows the progression of six increasingly denitrified RW 


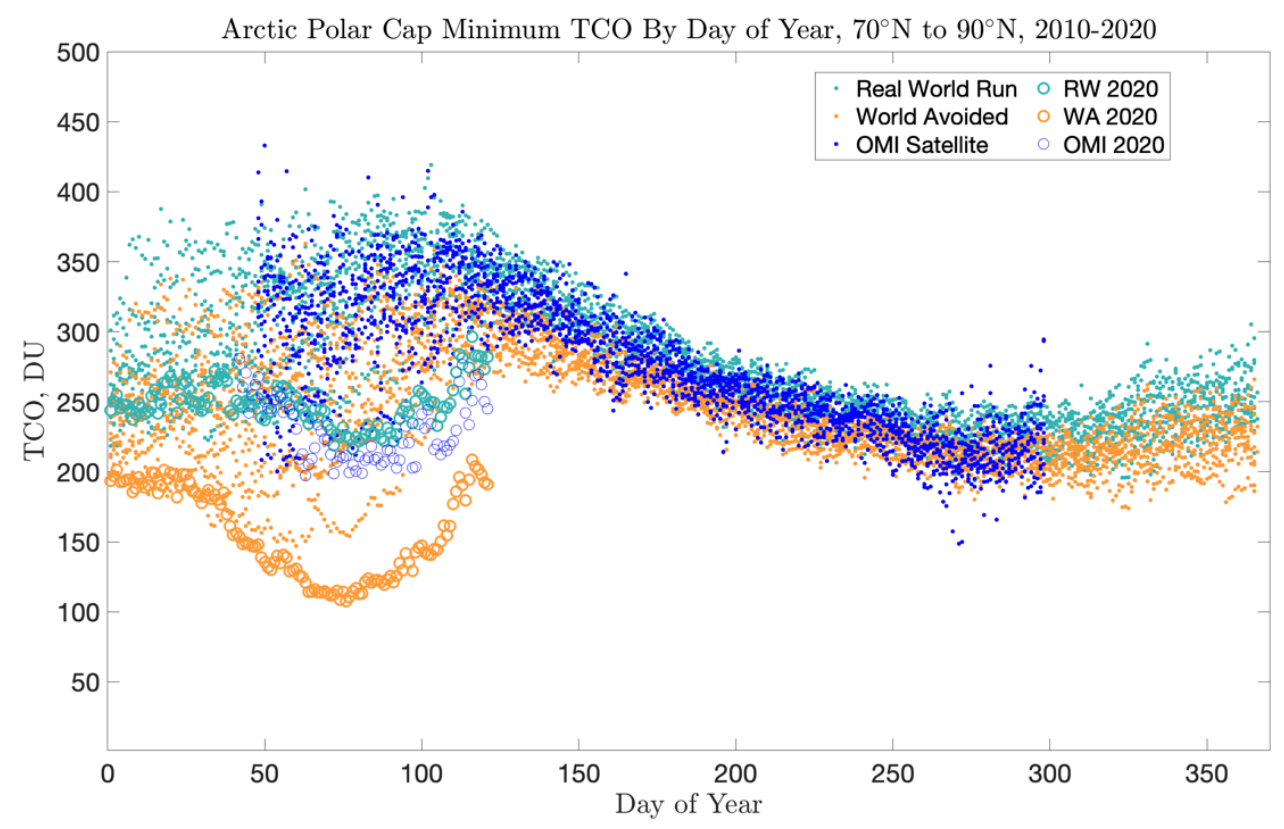

Figure 4. Minimum total column ozone simulated by SD-WACCM from $70^{\circ} \mathrm{N}$ to $90^{\circ} \mathrm{N}$ from January 2020 through April 2020, plotted by day of the year. Teal points refer to the reference run and orange to the world avoided run. Blue points refer to observations by the OMI Satellite. Dots indicate days prior to 2020 and open circles indicate days in 2020.

runs in the first two rows. Although the coverage of MLS data swaths (bottom row, middle panel) makes it difficult to distinguish which of the three highest denitrification levels is a better representation (middle row), the three lower denitrification levels (top panel) are much poorer matches to the observations. We ultimately found that a case adopting a NAT particle density of $10^{-5}$ particles per $\mathrm{cm}^{3}$ resulted in the closest match to observed ozone profiles, and so chose this value for our RW and WA simulations. As all of our RW runs adopt observed temperatures insofar as they can be determined from reanalysis, this study illustrates that accurate representation of denitrification (i.e., not only accurate temperature-driven reaction efficiencies but also PSC microphysics impacts) is key for ozone depletion under 2020 Arctic conditions.

Dramatic differences are obtained in the calculated and observed 2020 evolution of the dailyminimum TCO value over the Arctic polar cap by day of the year for the past decade in Figure 4 compared to the preceding years and especially for the World Avoided. While the RW and OMI satellite observations are consistently higher than the WA case, the scatter of the three from day to day overlaps before 2020. Further, both the RW run and the observations for 2020 spring display lower values than many WA springs, illustrating the key role of the unusually cold temperatures in 2020. The WA spring of 2020, 
(a)

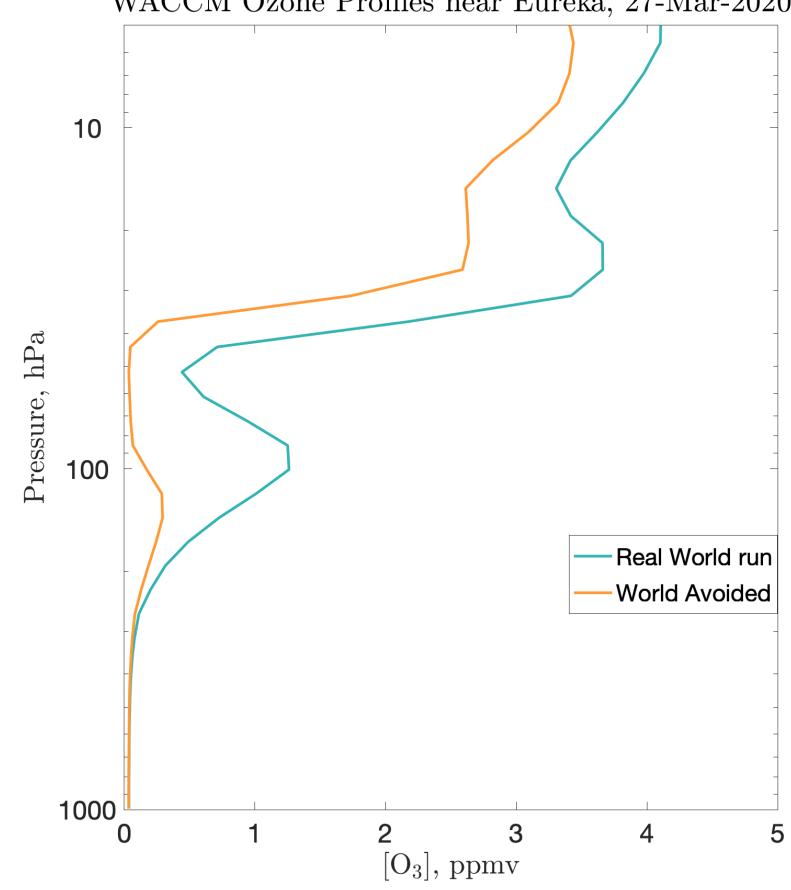

(b)

b) WACCM Ozone Profiles near Syowa, 01-Oct-2018

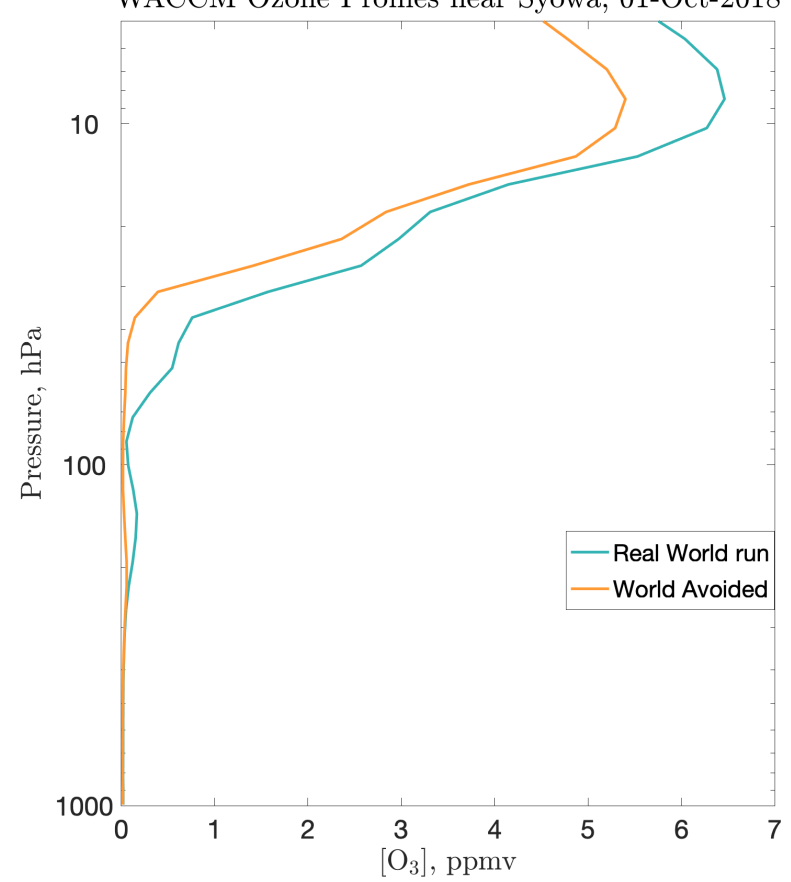

Figure 5. Comparison between the Real World and World Avoided profiles in SD-WACCM at the gridpoint (a) nearest to Eureka station for March $27^{\text {th }}, 2020$ and (b) nearest to Syowa station for October $1^{\text {st }}, 2018$.

however, drops to record lows early, and stays low longer than any other year. Furthermore, its apparent dip compared to the rest of the year resembles typical Antarctic ozone evolution (shown in Figure S4) rather than the typical Arctic behavior. The effects of higher chlorine loading in the WA scenario on the calculated ozone profile are also significant (Figure 5, left panel). While the RW displays a limited height region of extremely low ozone (see data in Figure 2), the World Avoided has almost no ozone left throughout the lower stratosphere. This resembles typical Antarctic depletion more than any previous year in the Arctic (Figure 5, right panel). Depletion in the lower stratosphere reaches these low values more quickly in the WA, and persists longer (Figure S4). At higher altitudes, where gas phase depletion identified by Molina and Rowland (1974) is dominant, substantial increases in depletion are also obtained (see below).

A characteristic finding of WA studies is that substantial polar ozone depletion eventually persists year-round (Newman et

205 al., 2009; Garcia et al., 2012). We can see the first indication of such behavior in our WA simulation for 2020 as shown in Figure 6, where the RW and WA total ozone time series are shown for the past decade (top panel), along with their difference (bottom panel). While for the first few years of the decade the summertime and autumnal differences between the 
(a)

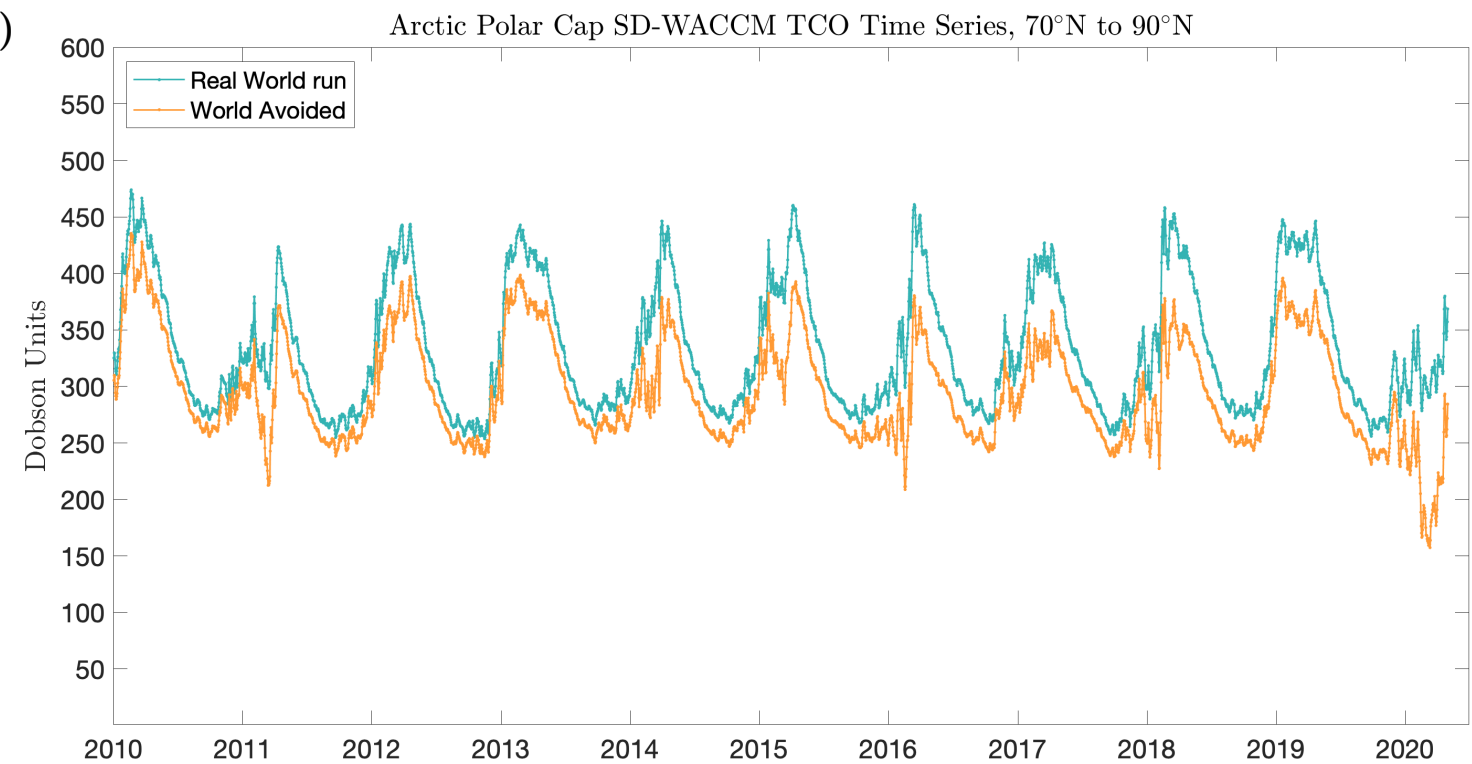

(b)

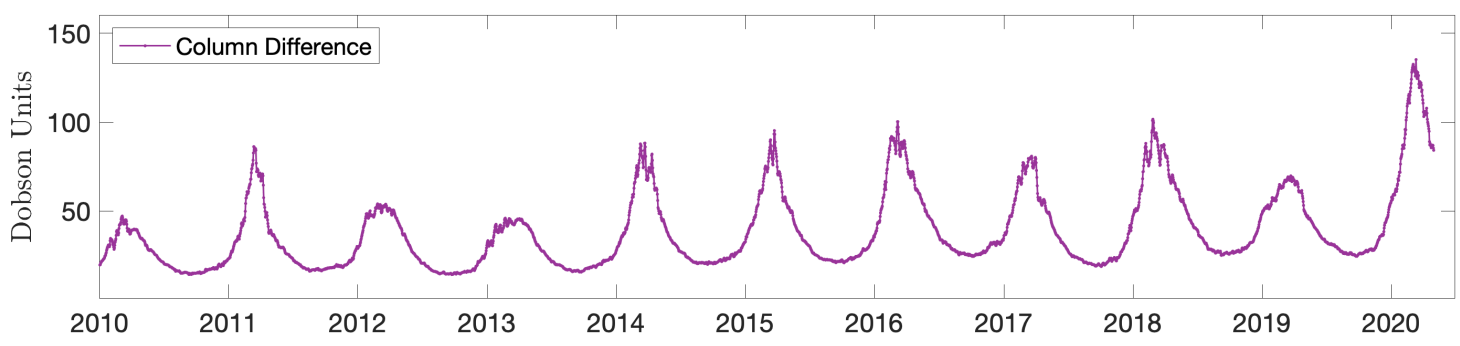

Figure 6. (a) Time series of mean SD-WACCM total column ozone across the polar cap for the Real World scenario (teal) and World Avoided scenario (orange) from January 2010 through April 2020. (b) The difference between the two.

scenarios remain low and fairly constant, after 2014 a noticeable trend towards increasing column difference year-round emerges. Much of this summertime difference is due to the gas-phase depletion, as demonstrated by the change in the profiles and increased partial column differences at higher altitudes (Figure S6). It is also noteworthy that while the spring of 2020 is anomalously depleted in the WA as previously shown, the spring ozone values obtained in 2018 and 2019 are also

215 much further from their RW counterparts, demonstrating the growing impact of the Montreal Protocol even for less cold years. 


\section{Discussion and Conclusions}

We have demonstrated that, were it not for the Montreal Protocol, in 2020 we should have expected the first Antarctic-like ozone hole to occur over the Arctic, an area with a substantial human population and vibrant ecosystem. The Arctic ozone hole would have begun earlier and persisted longer (see Figure S3) than the headline-grabbing 2020 ozone depletion in the real world did, with ozone all but completely destroyed over a large vertical extent of the lower stratosphere. Furthermore, our simulations support the view that there have already been substantial year-round benefits from the

Montreal Protocol for the Arctic. Finally, nitric acid observations and modelling for 2020 help improve our understanding of the role of denitrification in accurately assessing Arctic ozone loss, and further refinements of this will be the subject of future studies.

The main limitation of using a model constrained to real-world meteorology is that it by design eliminates any feedbacks that changes in ozone would have had on the meteorology. These are worthy of investigation in future free-running model simulations, especially in the context of potential increasing stratospheric Arctic cold extremes from climate change, which have been debated in the literature (Rex et al., 2004). In addition to the increased radiative forcing from increasing ODSs, ozone itself is a potent local greenhouse gas, and ozone depletion of the magnitude simulated here would significantly alter the temperature profile in the stratosphere and perhaps in the troposphere as well. Resultant changes in stratospheric

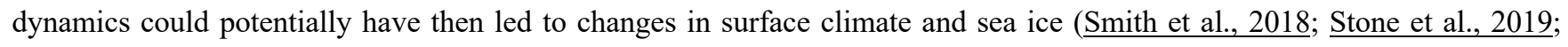

235 Stone et al., 2020). Surface UV increases could be especially important during the Arctic summer, when the vast majority of biological growth takes place; a coupled biosphere model could investigate such effects.

The benefits to society and the earth system achieved by the global community's adherence to the Montreal Protocol grow with each passing year, and can be dramatically documented in cold years with ozone depletion-favoring meteorology - in particular, 2020. As we progress further into the $21^{\text {st }}$ century, studies of the world we avoided will continue to be relevant to 240 both stratospheric science and environmental policy. When the Montreal Protocol was signed, the sophisticated modeling systems used for this and similar studies that can precisely simulate an alternate world did not yet exist. The basic science was, however, sound enough, and the risk clear enough, that society acted nonetheless. Here we have shown that our increased knowledge of what we would have faced has justified this past prudence. 
245 Author Contributions: D.K., S.S., and C.W. contributed to the modelling run setup and interpretation. D.T. contributed to data interpretation. All authors contributed to writing the paper.

Competing Interests: The authors declare that they have no conflict of interest.

Acknowledgments and Data Availability: C. W. and S. S. were partly supported by a gift from an anonymous donor to MIT. D. K. was funded in part by NASA grant (80NSSC19K0952). WACCM is a component of the CESM, supported by the National Science Foundation (NSF). We would like to acknowledge high-performance computing support from Cheyenne (doi:10.5065/D6RX99HX) provided by NCAR's Computational and Information Systems Laboratory, sponsored by the NSF. MERRA2, OMI, and MLS data can all be freely obtained online through NASA (https://gmao.gsfc.nasa.gov/reanalysis/MERRA-2/data access; https://disc.gsfc.nasa.gov/datasets/OMTO3e 003/summary; https://mls.jpl.nasa.gov/products/hcl_product.php). Ozonezonde station data can be accessed through the World Ozone and Ultraviolet Data Center (WOUDC, https://woudc.org/data/explore.php). Model results shown in this paper are available online (at: https://acomstaff.acom.ucar.edu/dkin/ACP_Wilka_2020/).

\section{References}

Bhartia, P. K.: Data from "OMI/Aura TOMS-Like ozone and radiative cloud fraction L3 1 day 0.25 degree x 0.25 degree V3,” (2012). NASA Goddard Space Flight Center, Goddard Earth Sciences Data and Information Services Center (GES DISC), Accessed: October $15^{\text {th }} 2020.10 .5067 /$ Aura/OMI/DATA3002

Birmpili, T.: Montreal Protocol at 30: The governance structure, the evolution, and the Kigali Amendment. Collect C R Geosci 350(7), 425-431 (2018).

Burkholder, J. B., Sander, S. P., Abbatt, J. P. D., Barker, J. R., Huie, R. E., Kolb, C. E., Kurylo, M. J., Orkin, V. L., Wilmouth, D. M. and Wine, P. H.: Chemical kinetics and photochemical data for use in atmospheric studies: Evaluation number 18. Technical Report, Pasadena, CA: Jet Propulsion Laboratory, National Aeronautics and Space Administration (2015).

Chipperfield, M. P., Bekki, S., Dhomse, S., Harris, N. R., Hassler, B., Hossaini, R., Steinbrecht, W., Thiéblemont, R. and Weber, M.: Detecting recovery of the stratospheric ozone layer. Nature 549, 211-218 (2017).

Chipperfield, M. P., Dhomse, S. S., Feng, W., McKenzie, R. L., Velders, G. J. and Pyle, J. A.: Quantifying the ozone and ultraviolet benefits already achieved by the Montreal Protocol. Nat Commun 6(1), 1-8 (2015).

Crutzen, P. J. and Arnold, F.: Nitric acid cloud formation in the cold Antarctic stratosphere: A major cause for the springtime 'ozone hole'. Nature 324(6098), 651-655 (1986). 
Danabasoglu, G., Lamarque, J. F., Bacmeister, J., Bailey, D. A., DuVivier, A. K., Edwards, J., Emmons, L. K., Fasullo, J., Garcia, R., Gettelman, A. and Hannay, C.: The Community Earth System Model version 2 (CESM2). J Adv Model Earth Syst 12(2), e2019MS001916 (2020).

Fahey, D. W., Gao, R. S., Carslaw, K. S., Kettleborough, J., Popp, P. J., Northway, M. J., Holecek, J. C., Ciciora, S. C., McLaughlin, R. J., Thompson, T. L. and Winkler, R. H.: The detection of large HNO3-containing particles in the winter Arctic stratosphere. Science 291(5506), 1026-1031 (2001).

Farman, J. C., Gardiner, B. G., and Shanklin, J. D.: Large losses of total ozone in Antarctica reveal seasonal ClO x/NO x interaction. Nature 315(6016), 207-210 (1985).

Garcia, R. R., Kinnison, D. E., and Marsh, D. R.: "World avoided" simulations with the whole atmosphere community climate model. J Geophys Res Atmos 117(D23) (2012).

Gelaro, R., McCarty, W., Suárez, M. J., Todling, R., Molod, A., Takacs, L., Randles, C. A., Darmenov, A., Bosilovich, M. G., Reichle, R. and Wargan, K.: The modern-era retrospective analysis for research and applications, version 2 (MERRA-2). J Clim 30(14), 5419-5454 (2017).

Gettelman, A., Mills, M. J., Kinnison, D. E., Garcia, R. R., Smith, A. K., Marsh, D. R., Tilmes, S., Vitt, F., Bardeen, C. G., McInerny, J. and Liu, H. L.: The whole atmosphere community climate model version 6 (WACCM6). J Geophys Res Atmos 124(23), 12380-12403 (2019).

Hofmann, D. J., Oltmans, S. J., Harris, J. M., Johnson, B. J., and Lathrop, J. A.: Ten years of ozonesonde measurements at the south pole: Implications for recovery of springtime Antarctic ozone. J Geophys Res Atmos 102(D7), 8931-8943 (1997).

Kerr, J. B., Fast, H., McElroy, C. T., Oltmans, S. J., Lathrop, J. A., Kyro, E., Paukkunen, A., Claude, H., Köhler, U., Sreedharan, C. R. and Takao, T.: The 1991 WMO international ozonesonde intercomparison at Vanscoy, Canada, Atmosphere-Ocean, 32(4), 685-716 (1994).

Kinnison, D. E., Brasseur, G. P., Walters, S., Garcia, R. R., Marsh, D. R., Sassi, F., Harvey, V. L., Randall, C. E., Emmons, L., Lamarque, J. F. and Hess, P.: Sensitivity of chemical tracers to meteorological parameters in the MOZART-3 chemical transport model. J Geophys Res 112(D20) (2007).

Langematz, U. M., Tully, N. C., Dameris, M., Laat, J. de., Klekociuk, A., Müller, R., and Young, P.: Polar stratospheric ozone: past, present, and future, Chapter 4 in Scientific Assessment of Ozone Depletion: 2018, Global Ozone Research and Monitoring Project-Report No. 58. World Meteorological Organization, Geneva, Switzerland, 20 (2018).

Lickley, M., Solomon, S., Fletcher, S., Velders, G.J ., Daniel, J., Rigby, M., Montzka, S. A., Kuijpers, L. J. and Stone, K.: Quantifying contributions of chlorofluorocarbon banks to emissions and impacts on the ozone layer and climate. Nat Commun 11(1), 1-11 (2020).

305 Manney, G. L., Livesey, N. J., Santee, M. L., Froidevaux, L., Lambert, A., Lawrence, Z. D., Millán, L. F., Neu, J. L., Read, W. G., Schwartz, M. J. and Fuller, R. A.: Record- low Arctic stratospheric ozone in 2020: MLS observations of 
chemical processes and comparisons with previous extreme winters. Geophys Res Lett 47(16) e2020GL089063 (2020).

Meinshausen, M., Vogel, E., Nauels, A., Lorbacher, K., Meinshausen, N., Etheridge, D. M., Fraser, P. J., Montzka, S. A., Rayner, P. J., Trudinger, C. M. and Krummel, P. B.: Historical greenhouse gas concentrations for climate modelling (CMIP6). Geosci Model Dev 10(5), 2057-2116 (2017).

Mills, M. J., Schmidt, A., Easter, R., Solomon, S., Kinnison, D. E., Ghan, S. J., Neely III, R. R., Marsh, D. R., Conley, A., Bardeen, C. G. and Gettelman, A.: Global volcanic aerosol properties derived from emissions, 1990-2014, using CESM1(WACCM). J Geophys Res Atmos 121(5), 2332-2348 (2016).

315 Molina, M. J. and Rowland, F. S.: Stratospheric sink for chlorofluoromethanes: chlorine atom-catalysed destruction of ozone. Nature 249(5460), 810-812 (1974).

Montzka, S. A., Dutton, G. S., Yu, P., Ray, E., Portmann, R. W., Daniel, J. S., Kuijpers, L., Hall, B. D., Mondeel, D., Siso, C. and Nance, J. D.: An unexpected and persistent increase in global emissions of ozone-depleting CFC-11. Nature 557(7705), 413-417 (2018).

Morgenstern, O., Braesicke, P., Hurwitz, M. M., O'Connor, F. M., Bushell, A. C., Johnson, C. E. and Pyle, J. A.: The world avoided by the Montreal Protocol. Geophys Res Lett 35(16) (2008).

Neely, R. R., and Schmidt, A.: "VolcanEESM: Global volcanic sulphur dioxide (SO2) emissions database from 1850 to present - Version 1.0.” (2016). https://doi.org/10.5285/76ebdc0b-0eed-4f70-b89e-55e606bcd568.

Newman, P. A., Oman, L. D., Douglass, A. R., Fleming, E. L., Frith, S. M., Hurwitz, M. M., Kawa, S. R., Jackman, C. H., Krotkov, N. A., Nash, E. R. and Nielsen, J. E.: What would have happened to the ozone layer if chlorofluorocarbons (CFCs) had not been regulated? Atmos Chem Phys 9(6) (2009).

O'Neill, B. C., Tebaldi, C., Van Vuuren, D. P., Eyring, V., Friedlingstein, P., Hurtt, G., Knutti, R., Kriegler, E., Lamarque, J. F., Lowe, J. and Meehl, G. A.: The scenario model intercomparison project (ScenarioMIP) for CMIP6, Geosci Model Dev 9, 3461-3482 (2016).

330 Prather, M., Midgley, P., Rowland, F. S., and Stolarski, R.: The ozone layer: the road not taken. Nature 381(6583), 551-554 (1996).

Rex, M., Salawitch, R. J., von der Gathen, P., Harris, N. R. P., Chipperfield, M. P. and Naujokat, B.: Arctic ozone loss and climate change. Geophys Res Lett 31(4) (2004).

Smit, H. G., Straeter, W., Johnson, B. J., Oltmans, S. J., Davies, J., Tarasick, D. W., Hoegger, B., Stubi, R., Schmidlin, F. J., Northam, T. and Thompson, A.M.: Assessment of the performance of ECC-ozonesondes under quasi-flight conditions in the environmental simulation chamber: Insights from the Juelich Ozone Sonde Intercomparison Experiment (JOSIE), J Geophys Res 112(D19), 563-18 (2007).

Tarasick, D. W., et al., Improving ECC Ozonesonde Data Quality: Assessment of Current Methods and Outstanding Issues, Earth Space Sci, in press 
Smit, H.G. and Kley, D.: JOSIE: the 1996 WMO international intercomparison of ozonesondes under quasi-flight conditions in the environmental chamber at Jülich, Proceedings of the XVIII Quadrennial Ozone Symposium, 971-974 (1998).

Smith, K. L., Polvani, L. M., and Tremblay, L. B.: The impact of stratospheric circulation extremes on minimum Arctic sea ice extent. J Clim 31(18), 7169-7183 (2018).

Sofieva, V. F., Kyrölä, E., Laine, M., Tamminen, J., Degenstein, D., Bourassa, A., Roth, C., Zawada, D., Weber, M., Rozanov, A. and Rahpoe, N.: Merged SAGE II, Ozone_cci and OMPS ozone profile dataset and evaluation of ozone trends in the stratosphere. Atmos Chem Phys 17(20), 12533-12552 (2017).

Solomon, S., Garcia, R. R., Rowland, F. S., and Wuebbles, D. J.: On the depletion of Antarctic ozone. Nature 321(6072), 755-758 (1986).

Solomon, S., Ivy, D.J., Kinnison, D., Mills, M.J., Neely, R.R. and Schmidt, A.: Emergence of healing in the Antarctic ozone layer. Science 353(6296), 269-274 (2016).

Solomon, S., Kinnison, D. E., Bandoro, J., and Garcia, R. R.: Simulation of polar ozone depletion: An update. J Geophys Res Atmos 120(15), 7958-7974 (2015).

Stolarski, R. S., Schoeberl, M. R., Newman, P. A., McPeters, R. D., and Krueger, A. J.: The 1989 Antarctic ozone hole as observed by TOMS. Geophys Res Lett 17(9), 1267-1270 (1990).

Stone, K. A., Solomon, S., and Kinnison, D. E.: Prediction of Northern Hemisphere regional sea ice extent and snow depth using stratospheric ozone information. J Geophys Res Atmos, e2019JD031770 (2020). https://doi.org/10.1029/2019JD031770

Stone, K. A., Solomon, S., Kinnison, D. E., Baggett, C. F., and Barnes, E. A.: Prediction of Northern Hemisphere regional surface temperatures using stratospheric ozone information. J Geophys Res Atmos 124(12), 5922-5933 (2019).

Strahan, S. E., and Douglass, A. R.: Decline in Antarctic ozone depletion and lower stratospheric chlorine determined from Aura Microwave Limb Sounder observations. Geophys Res Lett 45(1), 382-390 (2018).

Toon, O. B., Hamill, P., Turco, R. P., and Pinto, J.: Condensation of $\mathrm{HNO} 3$ and $\mathrm{HCl}$ in the winter polar stratospheres. Geophysl Res Lett 13(12), 1284-1287 (1986).

Waters, J. W., Froidevaux, L., Harwood, R. S., Jarnot, R. F., Pickett, H. M., Read, W. G., Siegel, P. H., Cofield, R. E., Filipiak, M. J., Flower, D. A. and Holden, J. R.: The earth observing system microwave limb sounder (EOS MLS) on the Aura satellite. IEEE Trans Geosci Remote Sens 44(5), 1075-1092 (2006).

Wegner, T., Kinnison, D. E., Garcia, R. R., and Solomon, S.: Simulation of polar stratospheric clouds in the specified dynamics version of the whole atmosphere community climate model. J Geophys Res Atmos 118(10), 4991-5002 (2013).

370 Wohltmann, I., von der Gathen, P., Lehmann, R., Maturilli, M., Deckelmann, H., Manney, G. L., Davies, J., Tarasick, D., Jepsen, N., Kivi, R. and Lyall, N.: Near-complete local reduction of Arctic stratospheric ozone by severe chemical loss in spring 2020. Geophysical Research Letters, 47(20), p.e2020GL089547 (2020). 